\title{
The effect of the therapeutic recreation program for children with autistic spectrum disorder on their social skills
}

Authors' Contribution: A Study Design B Data Collection C Statistical Analysis D Data Interpretation

E Manuscript Preparation F Literature Search G Funds Collection

\author{
Arzu Koçak Uyaroğlu1 ABDF, Ezgi Ertüzün² ABCG, Fatma Taş Arslan³ ABD \\ ${ }^{1}$ Department of Psychiatric Nursing, Faculty of Nursing, Selcuk University, Konya, Turkey \\ 2 Department of Recreation, Faculty of Sports Sciences, Selcuk University, Konya, Turkey \\ ${ }^{3}$ Department of Pediatric Health and Diseases, Faculty of Nursing, Selcuk University, \\ Konya, Turkey
}

\section{abstract}

Background: It is important that psychological structures have an impact on athlete performance, such as self-efficacy can be measured consistently. The aim of this study is to develop a measurement tool with psychometric properties that can measure the self-efficacy beliefs of athletes.

Material and methods:

The participants of the study consisted of 325 athletes (age $21.6 \pm 4.2$ ) who actively pursue sports in various sports branches in Turkey. In the validity and reliability analysis of the scale, exploratory and confirmatory factor analyzes were used. Cronbach's Alpha reliability coefficient value of the total scale is .88 .

Results: The validity and reliability analysis results of the scale revealed that the scale was generally in perfect fit. As a result, it can be said that the Athlete Self Efficacy Scale (ASES) is a valid and reliable measurement tool and can be used to determine the self-efficacy levels of adult athletes.

Conclusions: Validity and reliability studies of the Athlete Self Efficacy Scale should be repeated specific to the sport branch or in younger age groups. In addition, athlete's self-efficacy is a universal concept. In this respect, it is valid in other cultures and it is recommended to adapt the scale to other languages and cultures.

Key words: autism spectrum disorder, recreational therapy, social skill.

\section{article details}

Article statistics: Word count: 2,722; Tables: 3; Figures: 0; References: 39

Received: May 2020; Accepted: December 2021; Published: December 2021

Full-text PDF: http://www.balticsportscience.com

Copyright @ Gdansk University of Physical Education and Sport, Poland

Indexation: Celdes, Clarivate Analytics Emerging Sources Citation Index (ESCI), CNKI Scholar (China National Knowledge Infrastructure), CNPIEC, DOAJ, EBSCO - Central \& Eastern European Academic Source, EBSCO - SPORTDiscus, EBSCO Discovery Service, Google Scholar, Index Copernicus, J-Gate, Naviga (Softweco, Primo Central (ExLibris), ProQuest - Family Health, ProQuest - Health \& Medical Complete, ProQuest - Illustrata: Health Sciences, ProQuest Nursing \& Allied Health Source, Summon (Serials Solutions/ProQuest, TDOne (TDNet), Ulrich's Periodicals Directory/ ulrichsweb, WorldCat (OCLC)

Funding: This study was funded by the Selcuk University, Turkey, Unit of Scientific Research Projects Coordination.

Conflict of interests: Corresponding author:

Open Access License:
Authors have declared that no competing interest exists.

Arzu KOÇAK UYAROĞLU, Selcuk University Fakulty of Nursing, Department of Psychiatric Nursing, Konya, Turkey, Phone: +90 332223 3538, e-mail: asukocak51@gmail.com.tr.

This is an open access article distributed under the terms of the Creative Commons Attribution-Non-Commercial-NoDerivatives 4.0 International (https://creativecommons.org/licenses/by-nc-nd/4.0/), which permits use, distribution, and reproduction in any medium, provided the original work is properly cited, the use is non-commercial and is otherwise in compliance with the license. 


\section{INTRODUCTION}

Autistic spectrum disorder (ASD) can be defined as a life-long neurodevelopmental disorder that affects the social relationships and behaviors of an individual, leading to limitations in creative thinking [1-3]. It is argued that the most critical element in the definition of autism is the deterioration in social behaviors [4] and that individuals with autism experience difficulties in initiating and maintaining social relationships and interactions [5, 6]. Previous studies revealed that although the children with ASD want to establish a social relationship, their inefficacy in social skills prevents them from establishing and maintaining friendships $[7,8]$, and they find it difficult to gain acceptance from their peers and experience social isolation [9], which contributes to exhibiting destructive behaviors [10]. Matson et al. [11] state that a lack of social skills is at the center of problems of children with ASD, and the primary goal is to minimize this deficiency.

In this context, it is thought that physical activity programs for children with ASD may be beneficial in overcoming social skills deficiency and in increasing social interaction [12-14]. Groups of recreational sports activities which are specific to children with ASD and which include treatment and entertainment are not only an effective method for the development of physical capacities of children but also for changing their behavior [12, 15-18]. The related literature shows that participation of children with ASD in recreational sport activities contributes to their social interaction and communication skills [15, 19-23]. In brief, it can be said that therapeutic recreation programs (TRP) are an effective approach to address the problems experienced in many areas, such as autism-related social behavior [24], communication skills [25] and sensory and social skills [26]. In an experimental study, İlhan [27] examined the effect of physical education and sports activities on the socialization levels of trainable mentally disabled children and revealed that progress has been made in the socialization sub-dimensions of participation in group activities, communication and sharing with others. Similarly, Temel et al. [19] aimed to investigate the effect of sports on the levels of aggression and social adaptation in autistic children. They found that there were significant differences in the levels of social adjustment and aggression between autistic children who did sports and those who did not. In the international literature, there are studies that support the effect of TRPs on social skills [15, 20].

Exercise-based interventions in the literature involve one type of sport generally [28]. In this study, the development of social skills in children with ASD who encountered two different types of sports was investigated. In their meta-analysis study, Huang et al. [28] stated that the physical, psychological and social benefits of exercise-based interventions are obvious, but different types of interventions are needed. In Turkey, TRPs for children with ASD are not at a desired level, and there are few studies conducted in experimental design aiming to examine the effects of therapeutic recreation programs for children with ASD on the variables such as children's social skills, communication and social interaction $[19,29]$. In this respect, this study is expected to make a significant contribution to the development of training programs and to the field. The study was carried out to examine the effect of TRP for children with ASD on their social skills. Thus, the study addresses the following research question: Is there a significant difference between the pre-test and post-test scores of children with ASD in terms of the social skill levels?

\section{MATERIAL AND METHODS}

This was a one-group pretest-posttest pre-experimental study conducted among mothers of children with ASD (January 2018 - July 2018) [30] in a training center for individuals with autism spectrum disorder in the city center of Konya, Turkey. 


\section{PARTICIPANTS}

The research population was composed of the mothers of children who newly enrolled in an ASD education center in the city center of Konya in the 2017-2018 academic year. Our aim was to reach the whole population $(n=40)$. However, the mothers of the children who did not take both swimming and sports training at the center $(\mathrm{n}=6)$ and two mothers who did not agree to participate in the study (8 mothers in total) were excluded from the study. Therefore, the study group consisted of 32 mothers.

\section{DATA COLLECTION TOOLS}

The data were collected using the Family Information Form, including the participants' sociodemographic characteristics, and the Autism Social Skills Profile (ASSP) Scale.

Family Information Form. The information form prepared by the researchers consisted of 8 items related to the sociodemographic characteristics of the child with ASD and the family (the child's age and gender, number of siblings, attendance at a non-formal educational institution, age of starting education, mother's age, mother's educational and marital status).

Autism Social Skills Profile (ASSP) Scale. The original scale developed by Bellini and Hopf [31] for children with ASD consists of 45 items and 3 sub-dimensions. These sub-dimensions are Social Reciprocity, Social Participation/Avoidance, and Harmful Social Behaviors. Some items of the scale, which was adapted in Turkish by Demir [32], were found to be under different factors compared to the original scale, and thus, these items were removed from the scale. As a result, there are 41 items and 3 sub-dimensions in the Turkish version of the scale. Each item is scored on a 4-point Likert-type scale ( $1=$ never, $2=$ sometimes, $3=$ often, $4=$ always). A high total score refers to increased social skills. The Cronbach's alpha coefficient of the scale was found to be 0.84 .

\section{DATA COLLECTION}

The data were collected in two stages. In the first stage, pre-tests were performed. After the children with ASD enrolled in the center, the data were collected using the Family Information Form and the Autism Social Skills Profile (ASSP) Scale in the waiting room of the center under the supervision of the researcher. In the second stage, post-tests were performed. The data were collected from the mothers who completed all 16 sessions of the TRP; the ASSP Scale was applied under the supervision of the researcher.

\section{PROCEDURES}

The "TRP" for children with autism involved in the study group consisted of a total of 16 sessions, eight of which were swimming activities and eight of which were physical activities (Table 1). The relevant literature was reviewed by the researchers to determine the content of the program and the number of sessions [24, 33, 34]. The program was planned as two sessions per week and approximately 60 minutes per session. One of the weekly sessions was for swimming activities, while the other one was for physical activities. In the execution of the program, the swimming activities were conducted by trainers with the Special Athletes Trainer certificate, while the physical activities were conducted by trainers with the Special Athletes Gymnastics certificate. TRP was applied according to the Applied Behavior Analysis (ABA) model. Applied Behavior Analysis is used in sports and athletic training to teach and reinforce skills used in training. Trainers' applications according to the ABA model are as follows: systematic use of verbal instruction and feedback, positive and negative reinforcement, positive practices and time outs [35]. The positive feedback of the trainer is important in the therapeutic recreation program based on Applied Behavior Analysis. For example, when the child with ASD catches five balls at the command of the trainer, the trainer approves. Mothers of children with autism spectrum disorder did not actively participate in the therapeutic recreation program. They brought children to the 
center. The trainers received in-service training once a week and had at least five years of experience. During the program, it was observed that the development of swimming and physical activity skills of children with autism differed from one another. However, since the aim of the study was to improve the social skills of children with the autistic spectrum disorder, their willingness to adapt to the new environment and to continue the program was important. For this reason, their attendance at the program and experiencing the sessions was considered sufficient.

Table 1. The content of the TRP

\begin{tabular}{|c|c|c|}
\hline Week & Session & Content \\
\hline \multirow[t]{2}{*}{ Week 1} & $\begin{array}{l}\text { Session I } \\
\text { Swimming Activity }\end{array}$ & $\begin{array}{l}\text { Getting acquainted with the positive approach of the trainer, sitting on the } \\
\text { edge of the pool, and then hitting the water with feet turning back and } \\
\text { front, standing and walking in the pool with the help of the trainer, walking } \\
\text { toward the trainer alone, monitoring the trainer to build up trust, and playing } \\
\text { communication games in water (collecting balls in the pool, etc.) }\end{array}$ \\
\hline & $\begin{array}{l}\text { Session II } \\
\text { Physical Activity }\end{array}$ & $\begin{array}{l}\text { Walking in the gym, touching the sports equipment, and playing flexibility, } \\
\text { bounce and throwing the ball to the target games with a positive approach of } \\
\text { the trainer }\end{array}$ \\
\hline \multirow[t]{2}{*}{ Week 2} & $\begin{array}{l}\text { Session III } \\
\text { Swimming Activity }\end{array}$ & $\begin{array}{l}\text { Sitting on the edge of the pool, and then hitting the water with feet turning } \\
\text { back and front, standing and walking in the pool with the help of the } \\
\text { trainer, walking alone, monitoring the trainer to build up trust, and playing } \\
\text { communication games in water (collecting balls in the pool, etc.) }\end{array}$ \\
\hline & $\begin{array}{l}\text { Session IV } \\
\text { Physical Activity }\end{array}$ & $\begin{array}{l}\text { Playing flexibility, bounce, and throwing the ball to the target games with } \\
\text { the positive approach of the trainer, turning the body and head exercises for } \\
\text { flexibility }\end{array}$ \\
\hline \multirow[t]{2}{*}{ Week 3} & $\begin{array}{l}\text { Session V } \\
\text { Swimming Activity }\end{array}$ & $\begin{array}{l}\text { Warm-up activities in water (sitting on the edge of the pool and hitting the } \\
\text { water with feet turning back and front, standing in water and twisting the } \\
\text { arms), foot exercises with hands holding the edge of the pool, foot exercises } \\
\text { with a board, breathing exercises, games for breathing in water (bubble } \\
\text { making and bring red balls to me games, etc.) }\end{array}$ \\
\hline & $\begin{array}{l}\text { Session VI } \\
\text { Physical Activity }\end{array}$ & $\begin{array}{l}\text { Stretching exercises together with the trainer (reaching up with hands (apple } \\
\text { picking game), reaching out sideways, walking exercises on treadmills, } \\
\text { jumping from a height, walking on balance board with help, throwing balls at } \\
\text { the target. }\end{array}$ \\
\hline \multirow[t]{2}{*}{ Week 4} & $\begin{array}{l}\text { Session VII } \\
\text { Swimming Activity }\end{array}$ & $\begin{array}{l}\text { Warm-up activities in water (Sitting on the edge of the pool and hitting the } \\
\text { water with feet turning back and front, twisting arms standing in water), foot } \\
\text { exercises holding the edge of the pool, foot exercises with a board, breathing } \\
\text { exercises, games in the water (bubble making and bring red balls to me } \\
\text { games, etc.) }\end{array}$ \\
\hline & $\begin{array}{l}\text { Session VIII } \\
\text { Physical Activity }\end{array}$ & Flexibility, bouncing, balance, throwing balls at the target activities. \\
\hline \multirow{2}{*}{ Week 5} & $\begin{array}{l}\text { Session IX } \\
\text { Swimming Activity }\end{array}$ & $\begin{array}{l}\text { Warm-up activities with foot strokes, breathing exercises, sliding in water, and } \\
\text { standing in water while the head is inside and out (starfish and bring red balls } \\
\text { to me games) }\end{array}$ \\
\hline & $\begin{array}{l}\text { Session X } \\
\text { Physical Activity }\end{array}$ & $\begin{array}{l}\text { Flexibility, bouncing, balance, and throwing balls at the target activities. } \\
\text { Selecting student-specific activities varying from easy to difficult from each } \\
\text { stage }\end{array}$ \\
\hline \multirow{2}{*}{ Week 6} & $\begin{array}{l}\text { Session XI } \\
\text { Swimming Activity }\end{array}$ & $\begin{array}{l}\text { Warm-up activities with foot strokes, bubble games in water, sliding in water, } \\
\text { and standing in water while the head is inside and out (starfish and ball } \\
\text { collecting games) }\end{array}$ \\
\hline & $\begin{array}{l}\text { Session XII } \\
\text { Physical Activity }\end{array}$ & $\begin{array}{l}\text { Flexibility, bouncing, balance, and throwing balls to the target activities. } \\
\text { Selecting student-specific activities varying from easy to difficult from each } \\
\text { stage }\end{array}$ \\
\hline \multirow{2}{*}{ Week 7} & $\begin{array}{l}\text { Session XIII } \\
\text { Swimming Activity }\end{array}$ & $\begin{array}{l}\text { Warm-up activities with foot strokes, bubble games in water, foot exercises } \\
\text { with a board, staying in water games (starfish and ball collecting games) }\end{array}$ \\
\hline & $\begin{array}{l}\text { Session XIV } \\
\text { Physical Activity }\end{array}$ & Flexibility, bouncing, balance, and throwing balls at the target games \\
\hline \multirow{2}{*}{ Week 8} & $\begin{array}{l}\text { Session XV } \\
\text { Swimming Activity }\end{array}$ & $\begin{array}{l}\text { Warm-up with foot strokes, bubble games in water, foot exercises with a board, } \\
\text { staying in water games (starfish and ball collecting games) }\end{array}$ \\
\hline & $\begin{array}{l}\text { Session XVI } \\
\text { Physical Activity }\end{array}$ & Flexibility, bouncing, balance, and throwing balls at the target games \\
\hline
\end{tabular}




\section{DATA ANALYSIS}

The Statistical Package for the Social Sciences version 22.0 (IBM Corporation, New York, NY) was used to analyze the study data. The data showed normal distribution according to the Skewness-Kurtosis values. The quantitative data obtained from the mothers of children with ASD were analyzed with t-test in dependent groups in accordance with the purpose of the study. The effect size was calculated using Cohen's d formula in the G-Power 3.1 program and utilizing the t-test in the dependent groups. A sensitivity analysis was performed to assess the intervention effect. Standardized effect sizes (ESs) were calculated by dividing the adjusted between-group difference of the post-intervention means by the pooled baseline standard deviation. According to Cohen, ESs less than 0.2 indicate "no difference," ESs of 0.5 to 0.8 indicate "moderate differences," and ESs of 0.8 or greater indicate "considerable differences" [36]. The results were evaluated at 95\% confidence interval and the significance level of $\mathrm{p}<0.05$.

\section{ETHICAL CONSIDERATIONS}

Prior to the study, permission was obtained from the Ethics Committee of Selcuk University (40990478), Faculty of Sport Sciences and Selcuklu Individuals with Autism Foundation. The mothers participating in the study were informed about the significance of the study, and their informed consent was obtained. The mothers were ensured about the confidentiality of all the personal information about themselves and their children.

\section{RESULTS}

The mean age of the children with ASD was $7.5 \pm 3.25$ years. $21.9 \%$ of the children were female, and $78.1 \%$ were male. While $12.5 \%$ of the children with ASD had no siblings, $87.5 \%$ had a sibling. Nearly all the children with ASD attend an educational institution other than the center where the study was conducted. The mean age of starting school was $3.26 \pm$ 1.19. The mean age of the children's mothers was $39.06 \pm 7.20$ years, and $34.4 \%$ of the mothers were primary school graduates, while $31.3 \%$ were university graduates (Table 2 ).

Table 2. Demographic characteristics of the children with ASD $(n=32)$

\begin{tabular}{|c|c|c|c|}
\hline Variable & & Number & Percentage \% \\
\hline \multirow{2}{*}{ Gender } & Female & 7 & 21.9 \\
\hline & Male & 25 & 78.1 \\
\hline \multirow{2}{*}{$\begin{array}{l}\text { Attendance at General } \\
\text { Education Classes }\end{array}$} & Attending & 31 & 96.9 \\
\hline & Not attending & 1 & 3.1 \\
\hline \multirow{2}{*}{ Sibllings } & Yes & 28 & 87.5 \\
\hline & No & 4 & 12.5 \\
\hline \multirow{4}{*}{ Mother's education level } & Primary School & 11 & 34.4 \\
\hline & Secondary School & 6 & 18.8 \\
\hline & High School & 5 & 15.6 \\
\hline & University & 10 & 31.3 \\
\hline
\end{tabular}

The difference between the ASSP scale pretest and posttest mean scores of children with ASD was found to be statistically significant $(\mathrm{p}<0.05)$. It was found that mean scores of children with ASD increased after the TRP $(94.531 \pm 16.343)$ compared to the pre-program values (91.343 \pm 15.718$)$. The difference between the pre-test and post-test mean scores for the Social Reciprocity and Social Participation/Avoidance sub-dimensions of the scale was found statistically significant $(\mathrm{p}<0.05)$. The difference between the pre-test and post-test mean scores for the Harmful Social Behaviors sub-dimension was not statistically significant ( $p>0.05)$. It was found that the mean scores of children for the ASSP scale increased after 
the TRP $(94.531 \pm 16.343)$ compared to the pre-program values (91.343 \pm 15.718$)$. It was further revealed that the social skill levels of the children with ASD were positively affected by the program and the effect size was moderate at 0.437 (Table 3 ).

Table 3. Distribution of sub-dimension and total pretest and posttest mean scores of children with ASD $(\mathrm{n}=32)$

\begin{tabular}{|c|c|c|c|c|c|}
\hline \multirow{2}{*}{ Sub-dimensions } & \multirow{2}{*}{$\begin{array}{l}\text { Pretest } \\
\text { mean } \pm S S\end{array}$} & \multirow{2}{*}{$\begin{array}{l}\text { Posttest } \\
\text { mean } \pm S S\end{array}$} & \multicolumn{2}{|c|}{$\begin{array}{l}\text { Pretest - posttest } \\
\text { difference }\end{array}$} & \multirow{2}{*}{$\begin{array}{c}\text { Effect size (\%) } \\
95 \mathrm{Cl}) \\
\mathrm{d}\end{array}$} \\
\hline & & & $\mathrm{t}$ & $\mathrm{p}$ & \\
\hline Social Reciprocity & $27.000 \pm 8.171$ & $29.312 \pm 9.430$ & -4.377 & 0.000 & \multirow{4}{*}{$\begin{array}{c}0.437 \\
(0.017-0.856)\end{array}$} \\
\hline Social Participation/Avoidance & $27.406 \pm 9.404$ & $28.656 \pm 9.075$ & -2.353 & 0.025 & \\
\hline Harmful Social Behaviors & $36.937 \pm 4.376$ & $36.562 \pm 4.242$ & .773 & 0.445 & \\
\hline Total & $91.343 \pm 15.718$ & $94.531 \pm 16.343$ & -4.082 & 0.000 & \\
\hline
\end{tabular}

\section{DISCUSSION}

This study investigated the effect of the TRP for children with ASD on their social skills. The study was performed on a single group, and before and after the TRP, social skills were evaluated and the results were compared.

The most important finding in the study is that the TRP improved the social skills of children with ASD. These results are similar to those in the literature and it can be said that therapeutic recreation has an important role in increasing the social skills of children with ASD [12, $15,20,26,27]$. Participation in recreational sport activities is thought to contribute to the development of social skills as they encourage social interaction and enable children with ASD to integrate with their peers. García-Villamisar et al. [37] stated in their studies that therapeutic recreation has an indirect effect on the social skills of individuals with ASD. Pan [24] investigated the effects of therapeutic swimming on the social behaviors of children with ASD and revealed that the program consisting of 10 sessions was effective on social behaviors. Similarly, Movahedi et al. [17] examined the effect of physical activities on the social functioning of children with ASD, and at the end of 14 weeks they found that there was a significant improvement in social functioning, and the follow-up study showed that this improvement continued.

In addition, it was found that TRP had a positive effect on the Social Reciprocity and Social Participation/Avoidance sub-dimensions, but there was no change in the Harmful Social Behaviors sub-dimension. Children with autism have a strong tendency to show disruptive behavior such as physical aggression and self-harm, and these destructive behaviors may increase when there is no intervention. In this context, it could be more effective to implement the therapeutic recreation programs to reduce and control the destructive behaviors that individuals with ASD exhibit as well as to provide special training practices, especially individual training programs at a very early age. Horner et al. [38] examined nine invasive studies in their systematic review and stated that special education interventions based on behavioral evaluation were effective in reducing disruptive behavior. Bahrami et al. [39] examined the effectiveness of Kata technique education on stereotypical behaviors of children with ASD. They gave Kata technique training to children with autism for 14 weeks in 4 sessions per week. Their results suggested a decrease in the stereotypical behavior of the children in the experimental group.

The study revealed that therapeutic recreation practices involving sports activities might have a positive impact on harmful behaviors in the long term. Elliott et al. [23] reported that planned physical activities are effective in bringing about a change in the inappropriate behaviors of individuals with autism. Similarly, Temel et al. [19] found that children with 
ASD had low levels of aggression and high social adaptation levels. They emphasized that doing sports regularly is effective in the life of autistic individuals in the same way as healthy individuals, and it has an important role in decreasing the frequency of harmful behaviors of autistic individuals and increasing their communication and social skills. However, the findings also suggest that longer-term interventions are necessary and intervention programs for children with ASD should be evaluated in the long term. In addition, it can be said that practices such as therapeutic recreation that are employed within the scope of special education program for children with ASD and that support education may increase the effectiveness of the program. Our results support this view.

The mean score of children with ASD for the ASSP scale significantly increased after the TRP, the social skills of the children with autism improved; and the effect size was close to medium according to Cohen's d formula [36]. In this context, it can be said that long-term and multidimensional interventions of programs for children with ASD may be a factor affecting the effect size.

\section{STUDY STRENGTHS AND LIMITATIONS}

The main strength of this study is that it is among the few studies that combine two different therapeutic recreational activities (physical exercise and swimming) in a single program. Nevertheless, there are some notable limitations. The lack of a control group and randomization in the study is an important limitation [30]. Another limitation is that the study was performed in one center. Furthermore, the small sample increases the risk of type II errors. This weakens the study's ability to draw strong conclusions and limits the generalizability of the results.

\section{CONCLUSIONS}

This study shows that the TRP positively affects children with ASD due to the limited leisure activities. In addition, the study shows that the 16-week physical activity and swimmingbased TRP positively affected the Social Skills Profile (ASSP) Scale's total score, which measures Social Skills, and the Social Reciprocity, Social Participation/Avoidance subdimension scores. However, the program was insufficient to cause a change in the harmful social behavior sub-dimension.

The results suggest that there is a need to develop therapeutic recreation programs for children with ASD and that a program with 16 sessions is not sufficient to achieve a change in harmful social behaviors. It is believed that long-term programs may support change in these children.

Future experimental studies in the field would require evaluating the effectiveness of the program by including different therapeutic recreation activities (horse riding, surfing, etc.) in the program and ensuring a longer program duration. In addition, it is thought that conducting randomized controlled studies in evaluating the effect of small group practices of the therapeutic recreation program on social skill development will contribute to the literature with a high level of evidence.

\section{ACKNOWLEDGEMENTS}

This study was funded by the Selcuk University, Turkey, Unit of Scientific Research Projects Coordination. We would like to thank the Selcuklu Autism Education Foundation for their support in conducting the study. We particularly thank the participants. 


\section{REFERENCES}

[1] Kanner L. Autistic disturbances of affective contact. Nerv Child. 1943;2(2):217-250.

[2] Craig J, Baron-Cohen RJ. Creativity and imagination in Autism and Asperger syndrome. J Autism Dev Disord. 1999;29:319-326. https://doi.org/10.1023/A:1022163403479

[3] Lyons V, Fitzgerald M. Critical evaluation of the concept of Autistic creativity. Rec Adv Autism Spectr Disord. 2013;1:771-791. https://doi.org/10.5772/54465

[4] Stella J, Mundy P, Tuchman R. Social and nonsocial factors in the Childhood Autism Rating Scale. J Autism Dev Disord. 1999; 29, 307-317. https://doi.org/10.1023/A:1022111419409

[5] McKinnon K, Krempa J. Social skills solutions: A hands-on manual for teaching social skills to children with autism. New York: DRL Books; 2002.

[6] Mobily KE, MacNeil RD. Therapeutic recreation and the nature of disabilities. Venture Pub.; 2002.

[7] Tse J, Strulovitch J, Tagalakis V, Meng L, Fombonne E. Social skills training for adolescents with Asperger syndrome and high-functioning autism. J Autism Dev Disord. 2007; 37(10):1960-1968. https://doi.org/10.1007/s10803-006-0343-3

[8] Baker JE. Social skills training for children and adolescents with Asperger syndrome and social communication problems. Shawnee mission, KS: Autism Asperger Publishing Company; 2003.

[9] Bauminger N, Kasari C. Loneliness and friendship in high-functioning children with autism. Child Dev. 2000;71:447456. https://doi.org/10.1111/1467-8624.00156

[10] Matson JL, Fodstad JC, Rivet TT. The relationship of social skills and problem behaviors in adults with intellectual disability and autism or PDD-NOS. Res Autism Spectr Disord. 2009;3:258-268. https://doi.org/10.1016/j. rasd.2008.07.001

[11] Matson, JL, Matson ML, Rivet TT. Social-skills treatments for children with autism spectrum disorders. An overview. Behav Modific. 2007;31(5):682-707. https://doi.org/10.1177/0145445507301650

[12] Todd T, Reid G. Increasing physical activity in individuals with autism. Foc Autism Oth Dev Disabil. 2006;21:167-176. https://doi.org/10.1177/10883576060210030501

[13] Ward SC, Whalon K, Rusnak K, Wendell K, Paschall N. The association between therapeutic horseback riding and the social communication and sensory reactions of children with autism. J Autism Dev Disord. 2013;43:2190-2198. https://doi.org/10.1007/s10803-013-1773-3

[14] Healy S, Nacario A, Braithwaite RE, Hopper C. The effect of physical activity interventions on youth with autism spectrum disorder: A meta analysis. Autism Res. 2018;11(6):818-833. https://doi.org/10.1002/aur.1955

[15] Devine MA, Ripp JAC. The role of therapeutic recreation with people on the autism spectrum. Therap Recr J. 2017; 51(2):VII. https://doi.org/10.1007/s10803-015-2643-y

[16] Bahrami F, Movahedi A, Marandi SM, Sorensen C. The effect of karate techniques training on communication deficit of children with autism spectrum disorders. Journal of Autism and Developmental Disorders 2016; 46(3), 978-986.

[17] Movahedi A, Bahrami F, Marandi SM, Abedi A. Improvement in social dysfunction of children with autism spectrum disorder following long-term Kata techniques training. Res Autism Spectr Disord. 2013;7(9):1054-1061. https://doi org/10.1016/j.rasd.2013.04.012

[18] Alexander MGF, Dummer GM, Smeltzer A, Denton SJ. Developing the social skills of young adult special Olympics athletes. Educ Train Autism Dev Disabil. 2011;46(2):297-310.

[19] Temel G, Yıldız T, Turan MB, Karaoğlu B. Sporun otistik çocuklarda saldırganlık ve sosyal uyum düzeyleri üzerine etkisinin incelenmesi. [Examination of the Effect of Sports on Aggression and Social Adjustment Levels in Autistic Children], İÜ Spor Bilimleri Dergisi. 2017;7(3):25-33. Turkish.

[20] Pan CY, Tsai CL, Chu CH, Sung MC, Huang CY, Ma WY. Effects of physical exercise intervention on motor skills and executive functions in children with ADHD: A pilot study. J Attent Disord. 2019;23(4):384-397. https://doi. org/10.1177/1087054715569282

[21] Celiberti DA, Bobo HE, Kelly KS, Harris SL, Handleman JS. The differential and temporal effects of antecedent exercise on the self stimulatory behavior of a child with autism. Res Dev Disabil. 1997;18:139-150. https://doi org/10.1016/S0891-4222(96)00032-7

[22] Szot Z. The method of stimulated serial repetitions of gymnastic exercises in therapy of autistic children. J Autism Dev Disord. 1997;27:341-342. https://doi.org/10.1023/A:1025862701128

[23] Elliott RO, Dobbin AR, Rose GD, Soper HV. Vigorous, aerobic exercise versus general motor training activities: Effects on maladaptive and stereotypic behaviors of adults with both autism and mental retardation. J Autism Dev Disord. 1994;24(5):565-576. https://doi.org/10.1007/BF02172138

[24] Pan CY. Effects of water exercise swimming program on aquatic skills and social behaviors in children with autism spectrum disorders. Autism. 2010;14(1):9-28. https://doi.org/10.1177/1362361309339496

[25] Hameury L, Delavous P, Teste B, Leroy C, Gaboriau J-C, Berthier A. Equine assisted therapy and autism. Annales Me'dico-Psychologiques. 2010;168:(655-659). https://doi.org/10.1016/j.amp.2009.12.019

[26] Bass MM, Duchowny CA, Llabre MM. The effect of therapeutic horseback riding on social functioning in children with autism. J Autism Dev Disord. 2009;39:1261-1267. https://doi.org/10.1007/s10803-009-0734-3

[27] İlhan L. Eğitilebilir zihinsel engelli çocuklarda beden eğitimi ve sporun sosyalleşme düzeylerine etkisi. [The effect of physical education upon the socialization levels of mentally handicapped children] Kastamonu Eğitim Dergisi 2008;16(1):315-324. Turkish

[28] Huang J, Du C, Liu J, Tan G. Meta-analysis on intervention effects of physical activities on children and adolescents with autism. Int J Environ Res Public Health. 2020;17(6):1950. https://doi.org/10.3390/ijerph17061950

[29] Yarımkaya E, İlhan EL, Karasu N. An investigation of the changes in the communication skills of an individual with autism spectrum disorder participating in peer mediated adapted physical activities. Ankara Unıversity Faculty of Educational Sciences Journal of Special Education. 2017;18(2):225-252.

[30] Erdoğan S, Nahçivan N, Esin N. Hemşirelikte araştırma-süreç uygulama ve kritik. [Nursing Research-Process, Application and Critical] Istanbul, Turkey: Nobel Tip Kitabevi; 2014. Turkish. 
[31] Bellini S, Hopf A. The development of the autism scial skills profile: A preliminary analysis of psychometric properties. Focus Autism Oth Dev Disabil. 2007;22(2):80-87. https://doi.org/10.1177/10883576070220020801

[32] Demir Ş. Otizm Sosyal Beceriler Ölçeği Autism Social Skills Profile (ASSP) Scale. Türkiye'de özel eğitim alanında geliştirilen ve uyarlanan ölçme araçları [Measures developed and adopted in special education in Turkey]. In: Kaner S, Bayraklı H, Diken I, Çelik S, editors. Ankara: Maya Akademi; 2012, 451-453. Turkish.

[33] Alaniz ML, Rosenberg SS, Beard NR, Rosario ER. The effectiveness of aquatic group therapy for improving water safety and social interactions in children with autism spectrum disorder: A pilot program. J Autism Dev Disord. 2017;47(12):4006-4017. https://doi.org/10.1007/s10803-017-3264-4

[34] Yılmaz I, Yanardağ M, Birkan B, Bumin G. Effects of swimming training on physical fitness and water orientation in autism. Pediatr Int. 2004;46(5):624-626. https://doi.org/10.1111/j.1442-200x.2004.01938.x

[35] Luiselli JK, Woods KE, Reed DD. Review of sports performance research with youth, collegiate, and elite athletes. J Appl Behav Analys. 2011;44(4):999-1002. https://doi.org/10.1901/jaba.2011.44-999

[36] Cohen J. Statistical Power Analysis for the Behavioral Sciences, 2nd Edition, New York: Routledge; 1988.

[37] García-Villamisar D, Dattilo J, Muela C. Effects of therapeutic recreation on adults with ASD and ID: A preliminary randomized control trial. J Intellect Disabil Res. 2017;61(4):325-340. https://doi.org/10.1111/jir.12320

[38] Horner RH, Carr EG, Strain PS, Todd AW, Reed HK. Problem behavior interventions for young children with autism: A research synthesis. J Autism Dev Disord. 2002;32(5):423-446. https://doi.org/10.1023/A:1020593922901

[39] Bahrami F, Movahedi A, Marandi SM, Abedi A. Kata techniques training consistently decreases stereotypy in children with autism spectrum disorder. Res Dev Disabil. 2012;33(4):1183-1193. https://doi.org/10.1016/j.ridd.2012.01.018 